\title{
Kálmánczi Antal
}

bírósági titkár, Debreceni Törvényszék

\section{A leggyakoribb tulajdon elleni szabálysértések gyakorlati problémái, különös tekintettel a lopásra és csalásra}

Debreceni Jogi Mühely, 2016. évi (XIII. évfolyam) 1-2. szám (2016. július 31.)

\section{Bevezető}

A technikai fejlödés, az elkövetési módok egyre újabb változatai következtében a büntető és szabálysértési jogszabályok állandó változást igényelnek. A változásokhoz természetszerüleg alkalmazkodni kell a jogalkalmazóknak is.

Napjainkban a tulajdon elleni szabálysértések az egyik leggyakoribb vagyon elleni szabálysértések, melyek vonatkozásában gyakran okoz problémát a büncselekményektől történő elhatárolás, illetve a tapasztalatok szerint az egyes cselekmények jogi megítélése is.

Ezen körülményekre tekintettel úgy éreztem, hogy érdeklődésre tarthat számot a dolgozatomban választott téma, mely hasznos lehet a gyakorlati jogalkalmazók számára.

Mindezekre figyelemmel hasznosnak véltem összegyüjteni a tulajdon elleni szabálysértésekkel, különösen a lopásokkal és csalásokkal kapcsolatban felmerülö leggyakoribb gyakorlati problémákat.

Dolgozatomban ennek megfelelően megpróbálom bemutatni a bírósági szabálysértési titkárként a központosított szabálysértés eredményeként nagyobb számban érkező tulajdon elleni szabálysértéssel kapcsolatos ügyiratok elbírálása során jelentkező leggyakoribb problémákat és a bűncselekményektől történő elhatárolásának nehézségeit.

\section{A tulajdon elleni szabálysértések hatályos törvényi tényállása}

A tulajdon elleni szabálysértéseket a szabálysértésekről, a szabálysértési eljárásról és a szabálysértési nyilvántartási rendszerről szóló 2012. évi II. törvény (továbbiakban: Szabs. tv.) 177. §-a szabályozza az alábbiak szerint:

Az (1) bekezdés értelmében:

,Aki

a) ötvenezer forintot meg nem haladó értékre lopást, sikkasztást, jogtalan elsajátitást, orgazdaságot,

b) ötvenezer forintot meg nem haladó kárt okozva csalást, szándékos rongálást,

c) ötvenezer forintot meg nem haladó vagyoni hátrányt okozva hütlen kezelést

követ el, úgyszintén, aki e cselekmények elkövetését megkísérli, szabálysértést követ el."

A (2) bekezdés szerint:

„Aki idegen, nem gépi meghajtású jármüvet mástól azért vesz el, hogy jogtalanul használja, szabálysértést követ el."

A (2a) bekezdés akként rendelkezik, hogy:

„Aki földmérési jelet vagy az államhatár megjelölésére szolgáló jelet elvisz, áthelyez vagy elmozdit, szabálysértést követ el."

A (3) bekezdés értelmében: 
„Aki a kulturális örökség védett elemeit, a megye-, város-, községhatár vagy a birtokhatár megjelölésére szolgáló hivatalos jelet vagy létesitményt, tömegközlekedési vagy távközlési eszközt, közúti jelzést, parkot vagy ahhoz tartozó felszerelést, természetvédelmi hatósági és tájékoztató táblát vagy egyéb közérdeket szolgáló jelet vagy létesitményt gondatlanul megsemmisit, megrongál, elvisz, áthelyez vagy elmozdit, szabálysértést követ el."

A (4) bekezdés szerint

„Az (1) bekezdés a) pontjában meghatározott szabálysértés miatt a közterület felügyelö, az erdészeti hatóság arra felhatalmazott ügyintézöje, a halászati őr, valamint a mezöör, a természeti, védett természeti és Natura 2000 területeken a természetvédelmi ör, helyi jelentöségü védett természeti területen az önkormányzati természetvédelmi ör is szabhat ki helyszini birságot."

Az (5) bekezdés kimondja, hogy:

„Az (1) és (2) bekezdésben meghatározott szabálysértés miatt szabálysértési eljárásnak csak magánindítványra van helye, ha a sértett az elkövetö hozzátartozója."

A (6) bekezdés értelmében:

„Az elkövetési érték, kár, illetve okozott vagyoni hátrány összegének megállapitása céljából érték-egybefoglalásnak van helye, ha az eljárás alá vont személy az (1) bekezdés a)-c) pontjában meghatározott ugyanolyan cselekményt több alkalommal, legfeljebb egy éven belül követte el és ezeket együttesen bírálják el. Nincs helye érték-egybefoglalásnak, ha az üzletszerü elkövetés megállapitható."

A tulajdon elleni szabálysértések közös jellemzője, hogy szabálysértési elzárással büntethetőek és - bár ez a szabálysértések jellegéből fakad - a büntetőeljárásokhoz képest adott esetben kisebb visszatartó erővel bíró szankcióval fenyegetettek.[1]

Fontos tudnunk, hogy 2016. január 1. napjáig a Szabs. tv. és maga a tulajdon elleni szabálysértések tényállása sem határozta meg az egyes szankcionálni rendelt cselekmények elkövetési magatartását, pontos fogalmát. Maga a Szabs. tv. nem utalt arra, hogy ezen cselekmények fogalmára a Büntető törvénykönyvről szóló 2012. évi C. törvény fogalmait kellene használni, azonban a 38/2012. (XI. 14.) AB határozat III. pontjában kimondta, hogy a Szabs. tv. kizárólag a „kriminális cselekmények” elleni fellépés eszközeként szabályozza a szabálysértést. A Szabs. tv. preambuluma „A társadalmi együttélés általánosan elfogadott szabályait sértö vagy veszélyeztetö, a büncselekményként történö büntetni rendeléshez szükséges kockázatokkal és veszélyességgel azonban nem rendelkezö kriminális cselekmények elleni hatékony fellépés" biztosításában határozza meg a törvényi szabályozás célját.

Jó ha tudjuk, hogy a Szabs. tv. mind felelősségi dogmatikájában, mind az eljárás szabályozásában büntetőjogi és büntető eljárásjogi megoldásokat alkalmaz.[2] De ebbe a körbe tartozónak lehet tekinteni a halmazati büntetésre, az ismételt elkövetésre vonatkozó szabályozást, vagy a szabálysértési nyilvántartás szabályait is.

Mivel a Szabs. tv. a szabálysértést kriminális cselekményként értékeli, szabályozását a „bagatell” büntetőjog irányába tolta el. Ezt a szabálysértésekről, a szabálysértési eljárásról és a szabálysértési nyilvántartási rendszerről szóló 2012. évi II. törvény és az azzal összefüggő egyes törvények módosításáról, valamint a katasztrófavédelemmel kapcsolatos egyes törvényi rendelkezések módosításáról szóló 2012. évi XXXI. törvény (Szabs. tv. mód.) indokolása egyértelmüen meg is fogalmazza:

„A Szabs. tv. preambuluma és 1. §-a egyaránt kriminális, törvény által büntetni rendelt, társadalomra veszélyes cselekményként definiálja a szabálysértéseket. Ezzel a megközelítéssel kvázi-trichotóm rendszer jött létre, a szabálysértési jogot egyértelmüen a büntetöjog felé közelitve. Ez a közeledés az áldozat szempontjából pozitivan értékelhetö, mivel számára a szabálysértés és a büncselekmény megélése között nincs jelentös különbség olyan 
szempontból, hogy mindkét esetben ö szenvedi el a kriminális cselekmény hátrányos következményeit."

Ezt az álláspontot alátámasztja a Szabs. tv. 2. §-ának (1) bekezdése is, mely szerint a szabálysértési felelősség szubjektív felelősségi forma, ugyanis a törvény rendelkezése szerint „Szabálysértés miatt az vonható felelösségre, akinek a cselekménye szándékos vagy gondatlan, kivéve, ha a szabálysértést meghatározó jogszabály csak a szándékos elkövetést bünteti." Tekintettel arra, hogy a vitatott tényállás nem egy magatartást (cselekedetet, vagy mulasztást), hanem egy objektív tényként fennálló élethelyzetet rendel büntetni, amellyel összefüggésben a bünösség nem értelmezhető, a tényállás lényegét tekintve az alanyi oldaltól független, gyakorlatilag objektív felelösséget teremt.

A teljesség kedvéért említést kell tenni a Legfelsőbb Bíróság Büntető Kollégiuma és a megyei bíróságok (a Fővárosi Bíróság) büntető kollégiumainak álláspontjáról a szabálysértésekről szóló 1999. évi LXIX. törvény (a továbbiakban: Sztv.) értelmezésével kapcsolatban, amely bár a korábbi törvényre vonatkozik, azonban a gyakorlatban a bírósági jogalkalmazás a fenti álláspont alátámasztására a mai napig használja.

Ezen álláspont az Általános kérdések között rögzíti, hogy a ,, szabálysértési jog anyagi jogi és eljárási szabályok egységes és önálló rendszere, de a szabálysértési felelösség, „, büntetöjogi” jellegü, a szabálysértési eljárás pedig a gyorsaság és az egyszerüsités követelményeinek érvényesitése mellett - leginkább a büntetöeljárásra jellemzö vonásokat mutat”.

Egyértelműen rögzíti továbbá, hogy „a szabálysértések elbírálása során alkalmazni kell azokat a büntetö anyagi jogi és eljárási fogalmakat (szabályokat), amelyekröl az Sztv. kifejezetten igy rendelkezik. „Értelemszerüen” figyelembe lehet venni azokat is, amelyekre az Sztv. utal, de részletes szabályozás nélkül, illetve amelyek az Sztv. szabályozását kiegészítik. Ennek az a feltétele, hogy a kisegitöleg figyelembe vett büntetö anyagi jogi vagy eljárási fogalom (szabály) nem ellentétes az Sztv. rendelkezéseivel és általános elveivel. A kisegítő jelleggel, értelemszerüen alkalmazotti jogszabályi rendelkezéseknek általában csak a tartalmára indokolt utalni, a pontos hivatkozás rendszerint szükségtelen.”

Ezen rendelkezések következménye az, hogy a bírósági határozatokban gyakorlatilag a büntetőjogból jól ismert fogalmak pusztán csak abban az esetben alkalmazhatóak, ha azok a Szabs. tv. rendelkezéseivel nem ellentétesek. Mindezeken túl a jogalkalmazó, jellemzően bírósági titkárokra azt a kötelezettséget is rója, hogy a Szabs. tv.-ben nem szabályozott fogalmakat ne használja „büntetőjogilag”, pusztán annak tartalmára utaljon, ugyanis a Szabs. tv. ezen fogalmakat sok esetben nem ismeri.[3]

A jelenleg hatályos Szabs. tv. azonban 2016. január 1. napjától kezdődően a 29. § (1) bekezdésének jelentős módosításával sok gyakorlati problémát megoldott. Jelen dolgozat tekintetében a legfontosabbnak az tekinthető, hogy a Szabs. tv. 29. §-a (1) bekezdésének j) pontja kimondja, hogy a Szabs. tv. eltérő rendelkezéseinek hiányában ,a Büntetö Törvénykönyvröl szóló törvény (a továbbiakban: Btk.) 370. § Lopás, Btk. 371. § Rongálás, Btk. 372. § Sikkasztás, Btk. 373. § Csalás, Btk. 376. § Hütlen kezelés, Btk. 378. § Jogtalan elsajátitás és a Btk. 379. $\S$ Orgazdaság tényállásoknak megfelelö szabálysértési tényállásokra....a különös részi tényállásokban meghatározottakat a szabálysértések tekintetében is alkalmazni kell".

Ezen jogszabály-módosítással gyakorlatilag a jogalkotó egyértelművé tette a már kialakult jogalkalmazói gyakorlatot és immár jogszabályi alapot teremtett a tulajdon elleni szabálysértések tekintetében a Btk. alkalmazására az egyes fogalmak és tényállások vonatkozásában.

Ezen elméleti bevezető után az egyes tulajdon elleni szabálysértések gyakorlati problémáinak részletes bemutatására kívánok rátérni. 


\section{Közös gyakorlati problémák}

Figyelemmel arra, hogy a tulajdon elleni szabálysértések esetén példának okáért a földmérési jel, vagy államhatár megjelölésére szolgáló jellel kapcsolatos szabálysértések elkövetése a gyakorlatban nem szokott előfordulni, a továbbiakban kizárólag a gyakorlati szempontból érdekesebb problémák ismertetésével kívánok foglalkozni.

Az egyik leggyakoribb közös probléma az értékhatároktisztázása, ugyanis gyakran tapasztalható, hogy a szabálysértési hatóság nem tesz eleget az értékhatárok pontos tisztázásának (pl.: bicikli esetében lemarad az azon található gyermekülés értékének tisztázása, amely szintén jogtalan eltulajdonításra került), mely a bíróságok szemszögéből tekintve azért jelentős probléma, mert a Szabs. tv. 64. §-ának (3) bekezdése szerint a szabálysértéssel okozott kár értékének megállapításához szakértő kirendelésére nincs lehetőség hivatalból.[4]

Ez az előkészítő eljárás során elkövetett mulasztás azt eredményezi, hogy a bíróság a szabálysértés elkövetése során nem tud pontos tényállást megállapítani, ennek következtében a sértett esetleges kártérítési igényének kérdésében sem tud érdemben döntést hozni, azt a Szabs. tv. 93. §-ának (4) bekezdése alapján egyéb törvényes útra kénytelen utasítani.[5] Mindezeken túl adott esetben éppen ezen figyelembe nem vett értékek miatt minősülhet büncselekménynek az eljárás alá vont személy szabálysértésként elbírált cselekménye, mely természetesen a perújítás lehetőségét rejti magában.

$\mathrm{Az}$ értékhatárok tisztázásakor a másik jelentős problémát véleményem szerint a nem kompetens személyektől kért értékmegállapítás jelenti. Gyakori probléma, hogy olyan személytől kérnek értékmegállapítást az előkészitő eljárásban a szabálysértési hatóságok, aki nem rendelkezik a szükséges hozzáértéssel, vagy nem állapítható meg az iratokból, hogy rendelkezik-e a szükséges kompetenciával.[6]

A gyakorlatban a leggyakoribb problémát az a sajnálatos módon még mindig megfigyelhető tendencia jelenti, miszerint a szabálysértési hatóság az előkészítő eljárások során nem vizsgálja az üzletszerüség, mint minősítő körülmény megállapíthatóságát minden esetben.

Amennyiben vizsgálata alapján mégis megállapíthatónak látja az üzletszerüséget, abban az esetben sem intézkedik - törvényi kötelező rendelkezés ellenére - a Szabs. tv. 45. §-ában írtaknak megfelelően az ügy haladéktalan áttétele iránt a hatáskörrel és illetékességgel rendelkezö hatóságokhoz.

Kérdésemre több esetben is azt a választ kaptam, hogy az általános nyomozó hatóságok ilyen esetben nem hajlandóak elfogadni a szabálysértési hatóság álláspontját, minden esetben vagy a bíróság végzésére, vagy az ügyészség nyomozást elrendelö átiratára várnak.

Az üzletszerüség kapcsán pusztán arra szeretném még felhívni a figyelmet, hogy az üzletszerü elkövetés nem állapítható meg, amikor a terheltek a lopási cselekményeket alkalomszerủen, néhány órán belül követték el.[7]

Ezen általános problémák bemutatását követően úgy gondolom, hogy szükséges az egyes tulajdon elleni szabálysértésekre jellemző további specifikus problémák bemutatása is, mely további hasznos iránymutatást jelenthet a jogalkalmazók számára.

\section{Egyes tulajdon elleni szabálysértések gyakorlati problémái Lopás}


A lopás a leggyakoribb tulajdon elleni szabálysértés. A cselekmény büntetőjogi tényállásának, mint háttérjoganyagnak az elemzésétől eltekintek, figyelemmel arra, hogy annak szabályai jól kimunkáltak, és azokkal a gyakorlatban probléma nem szokott előfordulni.

Inkább azokkal a jól körülhatárolható esetkörökkel foglalkozom, amelyek tekintetében felmerül a büncselekményektől történő elhatárolása.

A másik jelentős problémát a dolog elleni erőszak értelmezése jelenti. Ennek körében is az áramlopások megítélése okozza a legnagyobb nehézséget.

Az Ügyészség következetes gyakorlata szerint[8] ugyanis a dolog elleni erőszak megállapítására nincs lehetőség, amennyiben a lopás szükségszerű elkövetési tevékenysége a lopás elkövetési módja. Az Ügyészség álláspontja szerint amennyiben ezt a tipikus elkövetési módot dolog elleni erőszaknak tekintenénk, akkor az ehhez füződő jogi konzekvenciák mindig érvényesülnének és ennek következtében a szabálysértési értékre elkövetett gázlopás mindig vétségi alakzat lenne.

A problémát azonban az jelenti, hogy ezen eseti döntés óta jelentősen módosult a dolog elleni erőszak fogalma, és mára az élet is felülírta a tárgykörben született eseti döntéseket. A mai elkövetési módok egyre kifinomultabbak, az elkövetök pedig gyakran speciális eszközöket (pl.: speciális kulcsokat) gyártanak a jogtalan eltulajdonítási cselekmény végrehajtása érdekében. Ezt a folyamatot a szolgáltatók is indukálják, mivel egyre hatékonyabb védelmi eszközöket, megoldásokat igyekszenek kitalálni a fogyasztásmérő berendezések védelme érdekében.[9]

Álláspontom szerint[10] azonban ezt a többletmagatartást, nevezetesen, hogy a speciális védelemmel (pl.: csavarokkal) ellátott szerkezetek megbontását a szolgáltatók eszközeihez hasonló eszközök alkalmazásával hajtja végre az elkövető, értékelni kellene, de legalábbis igen körültekintően, alapos vizsgálatot követően (pl.: a szolgáltatók megkeresése útján, hogy milyen módon lehet a dugókat eltávolítani eszköz hiányában a csövekből) kellene egyértelműen elbírálni, és nem a jelenleg uralkodó gyakorlatnak megfelelően meghaladott eseti döntésekre hivatkozással visszaküldeni a Bíróságokra.

Az Ügyészségi álláspont véleményem szerint azért sem lehet helytálló, mivel példának okáért az „akasztásos módszer” egyértelmüen nem teszi lehetővé a dolog elleni erőszak, mint minősítő körülmény megállapítását, így nem minden esetben eredményezhetné az Ügyészség következetes álláspontjának felülvizsgálata a lopás vétségi alakzatának megállapítását.

Jelentős problémakört jelentenek újabban az erdőben jogellenes fakivágásokkal elkövetett lopások is. Ezen cselekmények megítélésénél nyilvánvalóan csak a fakivágások jöhetnek számításba a büncselekményi minősítő körülmények tekintetében, és példának okáért a fa gallyak összegyüjtése nem.

E körben problémát okozhat az is, ha a fa értékét a már fentebb ismertetett módon nem megfelelően állapítják meg. Csupán megjegyzem a teljesség érdekében, hogy a tényállás teljes körü tisztázása érdekében álláspontom szerint ilyen esetekben is szükséges a tulajdoni lap beszerzése, mely igen gyakran azonban elmarad.[11]

Bár az elkövetett cselekmény befejezettségének megállapítása nem gyakran okoz problémát, azonban ritkán még mindig előfordul, hogy nem helyesen kerül sor a cselekmény minősítésére.

A bírói gyakorlat töretlen abban, hogy amennyiben az elkövető a boltban a polcról levett terméket a ruházatába rejti, akkor befejezetté válik cselekménye.[12] 
Előfordul sajnos olyan eset is, amikor a gáz szabálytalan vételezésével elkövetett lopás a gáz jogosulatlan igénybevételének időtartamától függetlenül nem természetes egységként, hanem a cselekményt üzletszerüen elkövetettként értékeli a szabálysértési hatóság, és az ügy iratainak áttételre irányuló álláspontjával küldi meg a bíróság részére. Ez az álláspont azonban a BH. 2013. 177. számú eseti döntésben írtakkal ellentétes, ugyanis ilyen esetben sem a folytatólagosság, sem az üzletszerüség megállapítására nincs lehetőség.

Talán fölöslegesnek tünik felhívni rá a figyelmet, azonban mindenképpen figyelemmel kell lennünk arra is, hogy a lopás büncselekményének és szabálysértésének elhatárolásánál azt kell vizsgálni, hogy az elkövető szándéka milyen érték elkövetésére irányult. Erre betöréses és jármü-feltöréses lopások elkövetőinél - általában a helyszínen - az elkövetők által hozzáférhetővé vált és általuk reálisan elvehető legnagyobb értékek alapulvételével lehet következtetni.[13]

Az esetlegesen jelen lévő elkövetésben segítő társak[14] cselekményének jogi megítélése régebben több problémát is okozott, azonban jelenleg már nem szokott problémát okozni, így ezen problémakörrel részletesen magam sem kívánok foglalkozni. Csupán megjegyzem e vonatkozásban, hogy a büntetőjogi fogalmak használatára a Szabs. tv. 2016. január 1-jei módosításával szélesebb körben nyílt lehetőség a Szabs. tv. 29. §-a (1) bekezdésének módosítása révén.

Végül szeretném felhívni a figyelmet egy elhatárolási problémára, amely a napokban fordult elő az egyik szabálysértési ügyben. A kialakult és töretlen gyakorlat szerint lopás vétsége helyett jármü önkényes elvétele szabálysértésének minősül a kerékpár elvétele és másfél óráig tartó jogtalan használata, amikor az elkövetés körülményeiből nem lehet a fiatalkorú terhelt eltulajdonítási célzatára következtetni.[15] Az eseti döntés is kifejti, hogy a két cselekményt alapvetően a célzat határolja el. A lopásnál az eltulajdonítás, a jármü önkényes elvételénél a jogtalan használat a cél. A célzatra az elkövetés körülményeiből kell következtetéseket levonni, így pl. eltulajdonítási cél fennforgását bizonyítja, ha az elkövető a jármüvet szétszereli, és az alkatrészeit eladja, vagy ha a jármüvet hosszú időn át használja, valamint ha tartósan elrejti vagy eltagadja. A bírói gyakorlat szerint a hosszabb ideig, vagyis a több napig tartó használat utal a jogtalan eltulajdonítási célzatra. Abban az esetben azonban, ha az elkövető mondjuk a kerékpárt csak azért veszi el, hogy azzal lakóingatlanához menjen, majd hazaérve az utcán eldobja, nem lehet jogtalan eltulajdonítási célzatra következtetni.

\section{Csalás}

Mindenekelőtt fontosnak tartom megjegyezni, hogy a csalások elkövetésitárgya nemcsak dolog lehet, hanem létező vagy jövőben keletkező jog is. Lényeges, hogy a jogsértő cselekmény egy meghatározott személy vagyonát károsítsa, azonban a megtévesztett passzív alany és a sértett személye azonos és különböző is lehet, mivel nem tényállási feltétel az, hogy a kár kizárólag a megtévesztett személynél következhet be. A csalás sértettje egyebekben az, akinél a kár bekövetkezik.[16]

A gyakorlatban azonban nem mindig sikerül sajnálatos módon felismerni azt, hogy az elkövetési magatartás, a tévedésbe ejtés megkezdésével, illetve a felvilágosítás elmulasztásával a büncselekmény kísérleti stádiumába jut[17] amely mindaddig fennáll, amíg a kár be nem következik.[18] Tehát a csalás csak a kár bekövetkezésével válik befejezetté.

A csalás egy olyan cselekmény, amelynek tettese bárki lehet. A társtettességhez pedig az szükséges, hogy az elkövető közremüködjön a passzív alany megtévesztésében.[19]

Az elkövetési magatartás kapcsán kiemelést érdemel, hogy a büncselekményi törvényi tényállás alternatív elkövetési magatartást határoz meg, ugyanis tévedésbe ejtéssel, vagy tévedésben tartással is elkövethetővé teszi a csalás büncselekményét. A tévedésbe ejtés, illetve a tévedésben tartás elkövethető tevéssel és mulasztással is, azonban mindkét esetben 
szükséges az, hogy egyrészt másban a valóságtól eltérő tudattartalom kialakítását valósítsa meg, illetőleg ilyen - már kialakult - tudattartalmat megerösítsen, továbbá a passzív alanyt az elkövető magatartásától befolyásolva vagyoni rendelkezésre késztesse.

A tévedés fogalmának értelmezésével nem szokott probléma felmerülni, ezért ennek ismertetésétől eltekintek.[20]

A jelenleg uralkodó gyakorlat szerint nem bír relevanciával, hogy a tévedést kiváltó cselekmény mennyire volt összetett, nehezen felismerhető. Bármilyen egyszerü, könnyen felismerhető magatartás tanúsítása megállapíthatóvá teszi a csalást.[21]

A magatartásnak pusztán arra kell alkalmasnak lennie, hogy a sértett személyéhez kapcsolódóan előidézze a károkozást.[22]

Kérdésként merült fel abban az esetben, amikor a vevő a piacinál alacsonyabb árat kínál az eladónak a dologért, vagy a vevő csupán elfogadja az eladó által megjelölt alacsonyabb árat ismerve annak magasabb értékét - megvalósul-e a csalás.

A szabálysértési hatóság egy ilyen esetben szabálysértési felelősségre vonást kezdeményezett, azonban a bírói gyakorlat szerint ilyen esetben nem valósul meg csalás, mivel nem a csaló az, aki más tévedésben lévő személy ezen állapotát kihasználja. Álláspontom szerint ezen körülménynek a szankcionálása egyebekben a kereskedelem, a piacgazdaság alapelveit sértené, így a tévedésbe ejtés, vagy tévedésben tartás nem állapítható meg.

Fontosnak tartom kiemelni továbbá, hogy az elkövetés módját a törvényi tényállás jelenleg nem tartalmazza. A bírói gyakorlat a magatartás megtévesztésre való alkalmasságát a sértett szemszögéből vizsgálja, és adott esetben primitív megtévesztő magatartásokat is tényállásszerünek minősít.[23] Közömbös a sértett hiszékenysége, körültekintésének hiánya vagy gondatlan eljárása is.[24] Ez a körülmény azonban nem mentesít a pontos körülmények, elkövetési magatartások feltárásának kötelezettsége alól.

A gyakorlatban a leggyakrabban a csalás és lopás elhatárolása merül fel. A kialakult töretlen bírói gyakorlat szerint a lopás és a csalás tényállási elemei között a döntő elhatárolásnak más ismérveken felül - az alapja az, hogy a csalási cselekményeknél a sértett önmaga rendelkezik a távedésbe ejtés vagy tévedésben tartás hatására a vagyontárgy átadásáról, míg a lopásnál az elkövető a sértett tudta, beleegyezése nélkül jut az eltulajdonítani kívánt ingósághoz.[25]

Bár nem szorosan az elhatárolási kérdésekhez kapcsolódik, de említésre méltó probléma az a körülmény is - mely egyébként korábban számos esetben eltérő megoldáshoz vezetett -, hogy az internetes hirdetéssel megvalósított csalás esetén az elkövetési magatartás - a megtévesztés - akkor (és ott) valósul meg, amikor (és ahol) a sértett megnyitja a honlapon megtévesztési szándékkal közzétett eladási ajánlatot[26], vagyis ezen hely fogja megalapozni az illetékességet.

A teljesség kedvéért megemlítem, hogy az utóbbi időben egyre gyakoribb az az esetkör, amikor az elkövető beül egy étterembe, majd az ebéd elfogyasztását követően derül ki, hogy a számlát nem is tudja kifizetni. Ekkor csalást - és nem lopást - valósít meg az elkövető, mivel a sértettet tévedésbe ejtve, fizetési szándék nélkül vesz igénybe szolgáltatást, amelynek meg nem fizetése vagyonban bekövetkezett értékcsökkenésnek (kárnak) és nem elmaradt vagyoni előnynek tekintendő.[27]

\section{Sikkasztás}

Ezen szabálysértés megállapítására csak idegen dolog esetében kerülhet sor. Idegen dolognak azt tekintjük, amelynek az elkövető nem tulajdonosa, de idegen az a dolog is, amelynek a rábízó nem tulajdonosa. 
Fontos kiemelni azt is, hogy a birtokba adás jogcíme és annak időtartama is közömbös, azonban a dolognak megtekintés végett történő átadása - amely nem jár tényleges birtokátruházással - nem minősül rábízásnak.[28] Ugyancsak nem minősül rábízásnak a dolog pillanatnyi örizetére vagy felügyeletére vonatkozó felkérés sem.[29]

Ezen túlmenően nem szoktak problémák előfordulni az ilyen jellegü szabálysértések megítélésekor, ezért részletesebben ezen cselekményekkel magam sem kívánok foglalkozni.

\section{Jogtalan elsajátítás}

Az elkövetési magatartás lopáshoz történő hasonlósága miatt ezen cselekménytől történő elhatárolás okoz elsősorban a gyakorlatban problémát.

E körben szükséges tudnunk, hogy a dolognak a találással egyidejüleg történő megrongálása, elpusztítása - ha nincs birtokba vételi szándék - rongálás megállapítását teszi lehetővé.

A jogtalan elsajátítás csak szándékosan követhető el. Az elkövető szándékát kell minden esetben vizsgálni, melynek a tényállás valamennyi elemére ki kell terjednie. Ha a „találó” azt hiszi, hogy a dolog másnak a birtokából kiesett, de a valóságban birtokban volt, tévedés miatt nem lopásért, hanem jogtalan elsajátításért felelős.

Ha azonban elhagyottnak tudja - szándék hiányában[30] - a cselekmény nem valósul meg.[31]

\section{Orgazdaság}

A legfontosabb véleményem szerint ezen cselekmények elbírálásakor, hogy fel kell ismernünk, amennyiben az elkövető az alapcselekmény tettesének vagy részesének érdekében müködik közre a az elkövetett cselekményböl származó dologgal kapcsolatos magatartás kifejtésében, úgy bünpártolás valósul meg akkor is, ha az elkövetőnek is származik belöle anyagi haszna. Az orgazdaság ugyanis a tárgyi bünpártolás speciális alakzata, csak a Btk.-ban megjelölt alapbüncselekményekből származó dolgokra követhető el.

Az orgazdaság jogtalan haszonszerzésre irányuló célzatos cselekmény, amely csak egyenes szándékkal követhető el. Az elkövető tudatának át kell fognia azt, hogy a dolog, amelyet vagyoni haszon végett megszerez, elrejt, vagy annak elidegenítésében közremüködik az orgazdaság büntető törvényi tényállásában taxatíve felsorolt alapcselekmények valamelyikéből (leggyakrabban lopásból) származik.[32] Az elkövető tudattartamára - az arra vonatkozó beismerés hiányában - a külvilág számára is észlelhető, objektív tényekből és körülményekből kell következtetni, melyek minden esetben gondos mérlegelést igényelnek.

\section{Szándékos rongálás}

Ezen szabálysértések kapcsán véleményem szerint egyetlen momentum az, amire - még ha bagatellnek is tünik - érdemes felhívni a figyelmet, nevezetesen, hogy kizárólag idegen dolog szándékos megrongálása esetében merülhet fel ez a szabálysértés. Amennyiben ugyanis a saját dolog megrongálása pl.: biztosítási eseménnyel függ össze, esetlegesen a csalás akár büncselekményi, akár szabálysértési alakzatának a vizsgálata válhat indokolttá.

Jómagam más gyakorlati problémát ezen szabálysértések megítélése vonatkozásában nem tapasztaltam.

\section{Idegen, nem gépi meghajtású jármű elvétele}


Elsősorban azzal kell tisztába lennünk, hogy kizárólag a tettes számára idegen, nem gépi meghajtású jármü esetében kerülhet megállapításra ezen szabálysértés.

Gépi meghajtású az a jármü, amelyet beépített erőgép hajt, függetlenül az energiaforrás fajtájától. Elvételen a jármü feletti uralom egyoldalú megszerzését kell érteni.[33]

Lényeges tudnunk azonban, hogy nem követi el ezen szabálysértést az, aki csupán utasként ül be a más által elvett jármübe, még akkor sem, ha tudja, hogy az milyen módon jutott a vezető birtokába.[34]

Kizárólag akkor lesz felelősségre vonható, ha az elvételt megelőzően az utas az elvételt megelőzően támogatta a tettest.[35]

Az elkövetőnek tehát tudnia kell azt, hogy a nem gépi meghajtású jármü számára idegen és cselekménye jogellenes. A lopástól az különbözteti meg ezen szabálysértést, hogy az elkövetőnek a célja a jogtalan használat és nem az eltulajdonítás.

Ezen cselekmények megítélésében problémát jelenthet annak jogi megítélése, hogy mikor válik befejezetté az elkövetői magatartás. Erre a kérdésre a bírói gyakorlat adta meg a választ, mely szerint akár 300 méterre történő eltávolodás a helyszíntől is alkalmas a tulajdonos rendelkezése alóli elvonás, mint szükséges tényállási elem megállapítására, ezért a cselekmény már nem tekinthető a továbbiakban kísérletnek.[36]

\section{Kiemelt elkövetési tárgyra elkövetett gondatlan rongálás:}

Gyakorlati jelentősége igen elhanyagolható ezen szabálysértéseknek. Pusztán annyit kívánatos szem elött tartanunk, hogy a gondatlanságból elkövetett rongálás főszabályként kívül reked a büntető- és a szabálysértési jogi értékelésből. Kivételt képeznek a Szabs. tv. 177. §-ának (3) bekezdésben felsorolt tárgyak, az ezeket gondatlanságból érő rongálás ugyanis értékhatárra tekintet nélkül szabálysértés. A gondatlanul elkövetett nem kiemelt tárgyra nézve bekövetkező rongálásnak (pl. egy fészer dohányzás miatti felgyújtásának) sem szabálysértési, sem büntetőjogi következménye nincs.

\section{Érték-egybefoglalás}

Nincs tudomásom arról, hogy ezen Szabs. tv. 177. §-a (6) bekezdésében szabályozott jogintézménnyel bármilyen probléma előfordulna a gyakorlatban, azonban nem árt megjegyezni, hogy vizsgálata minden esetben elengedhetetlen. Fontos tudni, ugyanis hogy kizárólag üzletszerüség megállapításának hiányában kerülhet sor az érték-egybefoglalás szabályainak alkalmazására. A gyakorlatban azonban általában az üzletszerüség megállapítható lesz a legtöbb esetben, ezért elengedhetetlen a bünügyi és szabálysértési priuszok alapos vizsgálata.

\section{Bíróság elé állítások}

Ez az esetkör speciálisnak tekinthető a tulajdon elleni szabálysértéseken belül, figyelemmel arra, hogy a tulajdon elleni szabálysértések elzárással büntethetőek, ezért igen gyakran örizetbe vételre kerül sor ezen szabálysértések tekintetében.

Az egyik leggyakoribb problémát ennek következtében a bíróság elé állításos eljárások előfeltételeként jelentkező, az őrizetbe vételhez szükséges Szabs. tv. 73. §-ának (1) bekezdésében meghatározott tettenérés fogalmának értelmezése jelenti. A tettenérés fogalmát a Debreceni Járásbíróság már iránymutatásában értelmezte[37], melyet a Debreceni Törvényszék állásfoglalásában megerősített.[38] 
Az állásfoglalások lényege szerint a szemtanú jelenlétében elkövetett szabálysértés esetében alkalmazható a Szabs. tv. 73. §-a (1) bekezdésének 2. mondata, mely kiterjeszti a tettenérés fogalmát.[39] Amennyiben az ismeretlen elkövető szabálysértése elkövetésének nem volt szemtanúja, azaz az ismeretlen elkövetőt nem érték tetten, úgy ezen jogszabályhely nem alkalmazható.

A másik jelentős problémát az okozza, hogy gyakran a sértett személye nem kerül megfelelően beazonosításra, így a tárgyalás megtartásának törvényi akadálya lesz a Szabs. tv. 124. §-ának (2) bekezdése alapján. A leggyakrabban - a már hivatkozottaknak megfelelően a földek tulajdonjogának tisztázatlansága - lényegében a tulajdoni lapok hiánya - miatt nem lehet a sértett személyét megállapítani.

A bizonyítási eszközök hiánya, mint a Szabs. tv. 124. §-ának (2) bekezdésben megkívánt feltétel is igen gyakran fordul elö. Ezek az esetkörök rendkívül széles körüek, de a leggyakrabban az az eset tekinthető, amikor olyan személy kerül sértettként nyilatkoztatásra a közvetítői eljárásra, akinek ezen nyilatkozat megtételében a jogosultsága nem tisztázott, így az eljárás alá vont személy közvetítői eljárásra irányuló hozzájárulása esetén az ügyben érdemi döntés hozatalára nincs is lehetőség.[40]

A másik tipikusnak tekinthető probléma a tiltott prostitúció szabálysértés elkövetésekor az, amikor az eljárás alá vont személy tagadásával szemben kizárólag az intézkedő rendőrök olyan tartalmú jelentése áll, miszerint „kisminkelten, kihívó ruhában sétált” az eljárás alá vont személy a helyszínen. Ilyen esetekben az intézkedő rendőrök meghallgatása nem mellőzhető a rendszerint tagadó eljárás alá vont személy védekezésének ellenőrzése érdekében. Ezek hiányában a bizonyítékok hiánya miatt nincs lehetőség a gyorsított eljárás lefolytatására.

\section{Summary - The most common practical problems of summary offence against property, particulary theft and fraud}

In this study, based on the procedure of the Central Summary Offences in Hajdú-Bihar, I will try to present the most common practical problems of summary offence against property (particulary theft and fraud),

First of all, my article describes the legal background as to why summary offence procedure is called ,petty criminal law" in Hungary, and as a result what legal basis are being used for criminal concepts.

In the second part of the study I will present some resolution to the most common and the most important legal imperfections and problems.

Last but not least I will make an attempt to disclose the most common issues, which might occur in the so-called „quick procedure”, the „,bring to court”.

In summary I hope, my study can be of useful assistance to the summary offence procedure and can elevate standard/level of the procedure.

\section{Felhasznált irodalom}

Akácz József - Berkes György - Belegi József - Katona Sándor - Kónya István - Márki Zoltán - Mészáros Róza - Molnár Gábor - Rabóczi Ede: Magyar Büntetőjog I-III. Kommentár a gyakorló jogászok számára, Budapest HVG-ORAC kiadó, (2007-2012) elektronikus formátuma 
Csemáné Váradi Erika - Görgényi Ilona - Gula József - Lévay Miklós - Sántha Ferenc: Magyar Büntetőjog Különös Rész, 2. kötet, Budapest CompLex Kiadó, (2006)

Szerk.: Nagy Ferenc: A magyar büntetőjog különös része, Budapest HVG-Orac Kiadó (2009)

Felhasznált jogesetek és jogszabályok

BH 1985. 129. számú eseti döntés

BH 1988. 176. számú eseti döntés

BH 1989. 97. számú eseti döntés

BH 1989. 390. számú eseti döntés

BH 1990. 207. számú eseti döntés

BH 1990. 460. számú eseti döntés

BH 1991. 462. számú eseti döntés

BH 1992. 16. számú eseti döntés

BH 1992. 81. számú eseti döntés

BH 1992. 158. számú eseti döntés

BH 1994. 648. számú eseti döntés

BH 1995. 73. számú eseti döntés

BH 1999. 398. számú eseti döntés

BH 2005. 307. számú eseti döntés

BH 2010. 208. számú eseti döntés

BH 2011. 59. számú eseti döntés

BH 2011. 127. számú eseti döntés

BH 2011. 332. számú eseti döntés

BH 2013. 177. számú eseti döntés

EBH 2010. 2124. számú eseti döntés

FBK 1995/14.

38/2012. (XI. 14.) AB határozat

Felhasznált egyéb jogforrások

Debreceni Törvényszék Elnökének 2013.El.V.C.30/2. számú állásfoglalása

Debreceni Járásbíróság 2013.EL.V.C.12/2. számú állásfoglalása

DVD jogtár elektronikus formátuma

[1] Adott esetben azonban előfordulhat, hogy az eljárás alá vont személy elöéletére figyelemmel már elzárás büntetést indokolt kiszabni, míg a büntetőeljárás során próbára bocsátás, vagy esetleg megrovás intézkedések is alkalmazhatóak.

[2] A Szabs. tv. 29. §-a kimondja, hogy többek között a szándékosság és a gondatlanság, a kísérlet, társtettes és a közvetett tettes, a felbujtó és a bünsegéd, a hozzátartozó, a csoportos elkövetés, a nagy nyilvánosság fogalmára, a büntethetöséget kizáró okokra, valamint a magánindítványra a Büntető Törvénykönyvről szóló törvény által meghatározottakat a szabálysértésekre is alkalmazni kell.

[3] Ennek következménye az példának okáért, hogy a bírósági határozatokban a társtettesként történő elkövetés nem szerepel, csupán a súlyosító körülmények között utalás történik a társas elkövetési alakzat figyelembe vételére.

[4] A törvény pusztán akkor teszi lehetővé szakértő kirendelését, ha a szakértő kirendelését az eljárás alá vont személy vagy a sértett indítványozta és a szakértő várható költségét megelölegezi (Ebben az esetben egyébként kötelező is.). Ennek a gyakorlati jelentősége szinte elhanyagolható, a Debreceni Járásbíróságon és a Hajdúböszörményi Járásbíróságon ilyen eset nem fordult még elö. 
[5] Ez a probléma álláspontom szerint egy apró odafigyeléssel megoldható lenne, és az állampolgárok igazságszolgáltatásba vetett hitét is erősítené, nem beszélve arról, hogy talán az elkövetők is jobban meggondolnák a szabálysértési cselekmények elkövetését ha azt tapasztalják, hogy tulajdon elleni cselekményeknél minden esetben kötelesek az esetlegesen kiszabásra kerülő pénzbüntetés mellett az okozott kárt is megtéríteni.

[6] Elöfordult olyan eset, hogy a mobiltelefon kiskereskedelmi értékének megállapítása érdekében vaskereskedőtől kértek értékmegállapítást, mely álláspontom szerint nem elfogadható.

[7] BH 1991. 462. számú eseti döntés

A jogeset szerint a terheltek lopási szándéka hirtelen elhatározásból eredt, és kezdetben a saját gépkocsijukhoz szükséges kisebb értékü alkatrészek megszerzésére irányult, míg a további, ugyancsak alacsony értékü alkatrészek eltulajdonításának gondolata menet közben alakult ki. Cselekményüket egyetlen este, néhány óra tartama alatt követték el, magatartásukra az alkalomszerüség volt jellemző. Összességében az elkövetés módja, az eltulajdonított tárgyak értéke, jellege és a terheltek szándéka, kizárja az üzletszerüség fennállását.

[8] Ez a gyakorlat a BH 1992 158. és BH 1990. 207. számú eseti döntéseken alapul.

[9] Ilyeneknek tekinthetőek példának okáért a speciális csavarok is, amelyek a fogyasztásmérő berendezéseket védik és kizárólag speciális eszközökkel hajthatók ki.

[10] Mely egyebekben a Debreceni Járásbíróság szabálysértési titkárainak többségi álláspontja is.

[11] A tulajdoni lap beszerzését a tényállás pontos megállapításán túl az is indokolja, hogy abból lehet a sértett személyére egyértelmü következtetést levonni, így ennek tükrében lehet csak dönteni az esetleges közvetítői eljárásra utalás kérdésében.

[12] BH 1995. 73. és 1990. 460. számú eseti döntések

[13] BH 2005. 307. számú eseti döntés

[14] Gondolok itt elsősorban azokra, akik a terméket elrejtő személyt példának okáért takarják, stb.

[15] BH 1992. 81. számú eseti döntés

[16] BH 1988. 176. számú eseti döntés

[17] BH 1999. 398. számú eseti döntés

[18] DVD jogtár elektronikus formátuma

[19] BH 2011. 59. számú eseti döntés

[20] Pusztán annyit kívánok megjegyezni, hogy a tévedésnek nem kell kiterjednie a jogügylet egészére, csak az szükséges, hogy a jogügylet olyan elemeit fogja át, amelyek a károkozással okozati összefüggésben állnak.

[21] Csemáné Váradi Erika-Görgényi Ilona-Gula József-Lévay Miklós-Sántha Ferenc: Magyar Büntetöjog Különös Rész, 2. kötet, i.m. 422. o.

[22] Az FBK 1995/14. számú döntés azonban a védelem szükítésére irányuló igényt fogalmazott meg. A másodfokú bíróság szerint szükséges egy bizonyos határvonal meghúzása az elkövetési magatartás tévedést elöidéző (vagy tévedésben tartást fenntartó) alkalmasságának megítélésénél. Az ügyeiket önmaguk intéző személyeknek kellő gondossággal kell megvédeniük érdekeiket, ugyanis az államnak nem lehet feladata, hogy minden egyes ügylet felügyelöje, gondnoka legyen, az egészen átlátszó vagy naiv megtévesztésénél a kellő figyelmet pótolja, s ezáltal óvja meg ezen személyeket a káros következményektöl.

[23] DVD jogtár elektronikus formátuma

[24] Dr. Akácz József-Dr. Belegi József-Dr. Katona Sándor-Dr. Kónya István-Dr. Márki Zoltán-Dr. Mészáros Róza-Dr. Molnár Gábor-Dr. Soós László: Magyar Büntetőjog I-III. 
Kommentár a gyakorló jogászok számára, HVG-ORAC kiadó, Budapest, 2013. elektronikus formátuma

[25] BH 1994. 648. számú eseti döntés

[26] BH 2011. 332. számú eseti döntés értelmében a vádirat szerinti megtévesztés akkor történt, amikor az adott (konkrét) sértett az interneten szembesült a vádlott megtévesztő szándékkal internetre feltett és azáltal közvetített eladási ajánlatával. Ehhez képest a károkozó magatartás kifejtése (a pénzátutalás) és az eredmény (a kár) bekövetkezte is értelemszerüen a sértett lakóhelyén történt. Ekként valamennyi esetben ez (az adott sértett lakóhelye) az elkövetés helye.

A Legfelsőbb Bíróság kimondta továbbá, hogy az internetes szolgáltató (mint közvetítő) székhelye, valamint a vádlott lakó-, illetve tartózkodási helye és bankszámlájának helye közömbös.

[27] BH 2011. 127. és EBH 2010. 2124. számú eseti döntések.

Az eseti döntésben a Legfelsőbb Bíróság kifejtette, hogy a vagyon fogalmi körébe a következetes felfogásnak megfelelően a követelések és a vagyoni értékü jogok is beleértendők. A különböző szállítási, éttermi, szállodai szolgáltatások vagy a lakásbérlet egyaránt piaci értékkel bírnak. Attól függetlenül, hogy a szerződési szándék valós, avagy ezek valamelyikét az elkövetők jogtalan haszonszerzés végett, fizetési szándék nélkül szerzik meg, az annak ellenértékét képező díjra a sértett jogosultságot szerez. Az ellenérték megfizetésének elmaradása pedig a tényleges teljesítéssel megterhelt vagyonban értékcsökkenésként, és nem elmaradt haszonként jelentkezik. Ennek megfelelöen a bírói gyakorlat következetesen kárt okozó magatartásnak, ekként tényállásszerü csalás bűncselekményének (vagy szabálysértésének) tekinti a jogtalan haszonszerzés végett a sértetteket tévedésbe ejtő azon cselekményeket, amikor valamely terhelt fizetési szándék nélkül, e tekintetben a sértettet tévedésbe ejtve éttermi szolgáltatást, vasúti vagy más közforgalmú járművön személyszállítást vagy éppen szállodai elhelyezést vesz igénybe.

[28] Szerk.: Nagy Ferenc: A magyar büntetőjog különös része, Budapest HVG-Orac Kiadó (2009) 613. o.

[29] BH 2010. 208. számú eseti döntés

[30] BH 1989. 97. számú eseti döntés

[31] DVD jogtár elektronikus formátuma

[32] DVD jogtár elektronikus formátuma

[33] Szerk.: Nagy Ferenc: A magyar büntetőjog különös része, Budapest HVG-Orac Kiadó (2009) 637. o.

[34] BH 1989. 390. számú eseti döntés

[35] Példának okáért a BH 1985. 129. számú eseti döntés is ezt az álláspontot fejtette ki.

[36] BH 1992. 16. számú eseti döntés

[37] Debreceni Járásbíróság 2013.EL.V.C.12/2. számú állásfoglalása

[38] Debreceni Törvényszék Elnökének 2013.El.V.C.30/2. számú állásfoglalása

[39] A vonatkozó szabályokat akkor is alkalmazni rendeli, amikor a szabálysértés helyszínéről elmenekült elkövetőt a rendőrség az elkövetéstől számított 48 órán belül elfogja. [40] Ezen esetkör gyakran egyidejüleg azt is okozza, hogy nem lehet a sértett személyét megállapítani. 